\title{
Intercurrence between bovine leukosis virus infection and mastitis in dairy cattle
}

\section{Intercorrência entre a infecção pelo vírus da leucose bovina e a mastite em bovinos leiteiros}

\author{
Natália Amaral Ambrósio ${ }^{1 ;}$ Christian Hirsch2; Christiane Maria Barcellos \\ Magalhães Rocha²; Fábio Raphael Pascoti Bruhn³; Marcos Túlio Barcelos Lima'; \\ Dircéia Aparecida da Costa Custódio'; Juliana Rosa Silva1; Camila Prado Lenzi \\ Tadini; Geraldo Márcio da Costa²*
}

\section{Highlights}

A case-control study that demonstrates bovine leukosis is a risk factor for mastitis.

The prevalences of mastitis and leukosis in dairy cattle herds were evaluated.

The proportion of animals with persistent leukocytosis was determined in the study.

Cows with leukosis have higher levels of subclinical mastitis than uninfected ones.

\section{Abstract}

There are several factors affecting global milk production leading to severe economic losses. Mastitis and leukosis are highly prevalent diseases especially in Brazilian cattle herds. The present study aimed to evaluate the correlation between mastitis and the bovine leukemia virus (BLV) infection in naturally infected cows belonging to dairy herds in Minas Gerais State. Additionally, the prevalence of both diseases, pathogens causing mastitis, and their association with BLV infection and persistent lymphocytosis were evaluated. The prevalence of BLV was determined using the agar gel immunodiffusion test (AGID) in 1,392 lactating cows from ten dairy herds. From the AGID results, 240 cows were selected and divided into two experimental groups: A case group composed of 160 BLV-positive cows (BLV-P) and the control group of 80 BLV-negative cows (BLV-N). Based on serological and leucocytic evaluations, the animals were classified into three subgroups: BLV-N, BLV-P without persistent lymphocytosis (BLV-PWPL), and BLV-positive with persistent lymphocytosis (BLV-PPL). The California Mastitis Test (CMT) was performed on days 0 (D0) and 60 (D60) in the subgroups and the milk from CMT-positive glands were analyzed. BLV infection was present in $100 \%$ of herds, with an overall prevalence of $80.9 \%$ in cows older than 24 months. Among BLV-P animals,

1 Post Graduate Students, Faculdade de Zootecnia e Medicina Veterinária, Departamento de Medicina Veterinária, Universidade Federal de Lavras, UFLA, Lavras, MG, Brazil. E-mail: nataliaamaralambrosio@gmail.com; m_tuliolima@ hotmail.com; dirceiacosta2017@gmail.com; ju_rosa_silva@hotmail.com; camilalenzi@yahoo.com.br

2 Profs. Drs., Faculdade de Zootecnia e Medicina Veterinária, Departamento de Medicina Veterinária, UFLA, Lavras, MG, Brazil. E-mail: chhirsch@ufla.br; rochac@ufla.br; gmcosta@ufla.br

3 Prof. Dr., Faculdade de Veterinária, Universidade Federal de Pelotas, UFPel, Capão Leão, RS, Brazil. E-mail: fabio_ rpb@yahoo.com.br

* Author for correspondence

Received: Mar. 22, 2021 - Approved: Sept. 15, 2021 
$74 \%$ were classified as BLV-PWPL and $26 \%$ as BLV-PPL. Coagulase-negative Staphylococcus (73.30\%), Corynebacterium spp. (12.04\%), Streptococcus agalactiae (8.90\%), and Staphylococcus aureus (5.76\%) were predominant (61.41\%). There were no statistical differences among the scores of clinical or subclinical mastitis with the pathogen type (contagious or environmental) in the BLV-PWPL or BLV-PPL subgroups. However, BLV-P animals showed higher CMT scores than BLV-N animals, suggesting a higher predisposition to subclinical mastitis in cows affected by leukosis.

Key words: Bovine. Milk. Retrovirus. Intramammary infection. Bovine immunity.

\section{Resumo}

Tendo em vista a relevância econômica e social da produção de leite e a ampla ocorrência da leucose e mastite em rebanhos brasileiros, foi proposto o presente estudo com o objetivo de avaliar a correlação entre a mastite e a infecção pelo vírus da leucose bovina em vacas leiteiras naturalmente infectadas de 10 rebanhos leiteiros da região sul do estado de Minas Gerais. Além disso, foi avaliada a prevalência de ambas as doenças e dos patógenos causadores de mastite e sua associação com infecção por BLV e linfocitose persistente. A prevalência do VLB foi avaliada pelo teste de imunodifusão em gel de ágar (IDGA) em 1.392 vacas em lactação nos rebanhos estudados. De acordo com os resultados do IDGA, 240 vacas foram selecionadas para compor dois grupos experimentais: 1-caso: composto por 160 vacas BLV positivas (BLV-P) e 2-controle: composto por 80 vacas BLV negativas (BLV-N). De acordo com as avaliações sorológicas e leucocitárias, os animais foram classificados em três subgrupos: BLV-N; BLV-P sem linfocitose persistente (BLV-PWPL) e BLV positivos com linfocitose persistente (BLV-PPL). O California Mastitis Test (CMT) e a cultura do leite das glândulas CMT positivas foram realizados nos dias 0 (D0) e 60 (D60). A leucose foi detectada em $100 \%$ dos rebanhos com prevalência média de $80,9 \%$. Entre os animais BLV-P, 74\% foram classificados como BLV-PWPL e 26\% como BLV-PPL. Staphylococcus coagulase negativos (73,30\%), seguido por Corynebacterium spp. (12,04\%), Streptococcus agalactiae (8,90\%) e Staphylococcus aureus $(5,76 \%)$ foram os agentes predominantes. Não houve diferença estatística entre os escores de mastite clínica ou subclínica e nem entre o tipo de patógeno (contagioso ou ambiental) nos subgrupos de animais BLV-PWPL ou BLV-PPL relacionados ao BLV-N. No entanto, animais BLV-P apresentaram escores mais elevados no CMT em relação aos animais BLV-N, sugerindo maior predisposição à mastite subclínica em vacas com leucose.

Palavras-chave: Bovino. Leite. Retrovírus. Infecção intramamária. Imunidade bovina.

\section{Introduction}

Brazil is a prominent contributor to global milk production, but the average productivity of Brazilian cattle is still poor compared to those in other producing countries. This may be attributed to the occurrence of diseases that endemically affect its herds, such as mastitis and bovine leukosis.
Bovine leukosis is an infectious disease and its etiological agent, the bovine leukemia virus (BLV), belongs to the genus Deltaretrovirus of the family Retroviridae, according to the International Committee on Taxonomy of Viruses [ICTV] (2021). High prevalence of leukosis is generally observed in dairy cattle herds, it can cause several economic losses. These includes the premature disposal or death of animals with lymphoma, costs 
associated with the diagnosis and treatment of complications, condemnation of carcasses in slaughterhouses, international trade restrictions, and reduction in milk productivity (Birgel, Dias, Souza, Pogliani, \& Birgel, 2006; Norby, Bartlett, Byrem, \& Erskine, 2016; Yang et al., 2016).

Additionally, BLV infection affects the immune system of the animals, which can have a more significant impact on the general health of the herd than the direct losses associated with the development of lymphomas (Trainin \& Brenner, 2005). According to Della Libera et al. (2015), although BLV has tropism by B lymphocytes, the virus may affect the innate and adaptive immune response, because these systems display many common effector mechanisms. Hence, BLV-positive animals may be more prone to the development of other infectious diseases, including mastitis (Sandev, Koleva, Binev, \& Ilieva, 2004; Azedo, Blagitz, Souza, Benesi, \& Della Libera, 2011; Kakinuma, Maeda, Ohtsuka, Konnai, \& Oikawa, 2014; Yang et al., 2016; Watanabe et al., 2019).

Mastitis is one of the most economically relevant infectious diseases in dairy cattle herds worldwide (Costa, 2014; Rueg, 2017; Santos \& Fonseca, 2019). This disease causes the greatest economic losses due to the disposal of milk during treatment of affected animals, decreased production and lower quality of milk, treatment costs, and early disposal of chronically affected animals (Costa, 2014; Acosta, Silva, Medeiros, Pinheiro, \& Mota, 2016).

BLV infection is related to an increase in mastitis and high somatic cell counts in BLVpositive animals (Sandev et al., 2004). Silva et al. (2018) reported that low milk production in BLV-positive animals, especially in cows with persistent lymphocytosis, is associated with low phagocytic capacity and reduced production of reactive oxygen species by neutrophils present in these animals, which predisposes them to intramammary infections.

Given the economic importance of milk production and the wide occurrence of leukosis and mastitis in Brazilian bovine dairy herds, the present study aimed to evaluate the correlation between mastitis and BLV infection in naturally infected dairy cows belonging to dairy herds from the southern Minas Gerais State. Additionally, the prevalence of both diseases and pathogens causing mastitis and their association with BLV infection and persistent lymphocytosis were evaluated.

\section{Material and Methods}

The study was conducted in the mesoregion of Campo das Vertentes in the state of Minas Gerais, Brazil. This study was approved by the Ethics Committee on the Use of Animals (CEUA) of the Federal University of Lavras. Protocol No. 709/13.

\section{Cattle herd screening}

Data were collected from ten herds based on the following criteria: 1) genealogy (Dutch blood grade $7 / 8$ or higher), 2) the number of animals in lactation greater than or equal to 50, and 3) presence of both BLV and mastitis in the herd.

All the 10 herds included in the study (identified by letters $A$ to $\mathrm{J}$ ) were from the same region of the state and showed similar characteristics of management, including several risk factors for BLV infections: reuse of 
the palpation gloves and disposable needles, the use of milking machines, and poor or absence of sanitation for the animals in the herd.

Blood samples of all lactating cows were obtained by venipuncture and subjected to the Agar Gel Immunodiffusion Test (AGID) for the detection of specific antibodies against BLV antigens, according to the manufacturer's protocol for the diagnostic kit (TECPAR $^{\circledR}$ Laboratory - Curitiba, PR). Based on the results of serological tests, the animals were classified as BLV-positive (BLV-P) or BLVnegative (BLV-N).

\section{Subclassification of BLV-infected animals}

BLV-P cows were subjected to hematologic evaluations by dividing into two subgroups: BLV seropositive animals without persistent lymphocytosis (BLV-PWPL) and BLV seropositive animals with persistent lymphocytosis (BLV-PPL). The total number of blood leukocytes was counted using the hemocytometer method (Neubauer chamber). Differential leukocyte counts were performed under an optical microscope using blood smears stained with the rapid panoptic type kit. The hematological key proposed by Bendixen (1958) was used as a parameter to classify the animals according to the presence or absence of lymphocytosis. For the determination of the persistent lymphocytosis condition, hematological analyses were performed on four blood samples from each cow, obtained at 30-day intervals, totaling 90 days of follow-up, according to the model proposed by Modena et al. (1984).

\section{Monitoring the health of the mammary gland}

All animals selected for the case/ control study had their mammary gland health evaluated at two time points: D0, the first day of evaluation after classification of animals in cases (BLV-P) or controls (BLV-N), and D60, evaluation performed on the 60th day of follow-up. For the diagnosis of subclinical mastitis, the California Mastitis Test (CMT) was used as described by Costa (2014). The animal was considered positive for subclinical mastitis when it had a score greater than or equal to $1(+)$ in CMT in at least a quarter of the mammary gland in at least one of the evaluations performed at D0 or D60.

Clinical mastitis was diagnosed by observing clinical changes in the udder and visual aspects of the first three jets of milk from each breast quarter before milking using the Tamis test, as described by Costa (2014). Cows that presented lumps of pus and/or striations of blood or clinical manifestations compatible with inflammation of the mammary gland in at least one-quarter of the mammary gland at D0 or D60 were considered clinically affected.

A quantitative variable determined by summing the CMT scores and the results of the Tamis test performed on D0 and D60 were used to quantify the severity of mastitis for each animal: Negative CMT glands $\geq$ score 0 , traced CMT glands $\geq$ score 1, CMT glands $+\geq$ score 2, CMT glands $++\geq$ score 3 , and glands CMT $+++\geq$ score 4 . Atrophied or clinically affected mammary quarters are scored with an arbitrary value of ten (10).

Milk samples from the mammary quarters of the animals that showed a reaction 
greater than or equal to $2(+)$ in the CMT, or from those that showed clinical signs were collected for the isolation and identification of the etiological agents. For this purpose, individual milk samples were collected in sterile flasks after antisepsis of the teats. The samples were aseptically collected and transported under refrigeration to the laboratory, where microbiological analyses were performed following the methodology proposed by the National Mastitis Council (Oliver, González, Hogan, Jayarao, \& Owens, 2004).

\section{Case-control study}

For the correlation analyses between BLV infection and mammary gland health status, the cows were divided into cases and controls. The controls were selected among non-infected lactating females and the cases were selected among lactating cows infected by BLV, such that they had homology regarding milk production and days in lactation (DL) with another animal of the control group. As parameters of productive and reproductive homology, it was determined that both had the same number of parturitions and that the $D L$ was equal or close (the mean $\mathrm{DL}$ range was 17 days). Thus, one BLV-positive animal (case) and another animal of the BLV-negative group (control) with similar characteristics were selected to compose the case/control study. The animals in the control group were serologically monitored by AGID throughout the experimental period to verify the maintenance of the BLV-negative status. Any animal from the control group that presented seroconversion (serology positive for BLV) was excluded from the case-control study.
After evaluating the available animal data and serological results obtained through AGID, the cows were classified into 196 cases and 196 controls, totaling 392 animals. However, 152 animals were excluded from the study, including 116 cows in the control group due to seroconversion caused by BLV infection and 36 animals in the case group that had drying (end of lactation), discarded from the herds due to other causes or died. Thus, the final number of animals used in the case-control study was 240 , with 160 cases and 80 controls.

\section{Statistical analysis}

To investigate the effects of BLV infection on the mammary glands of bovines, some variables related to the diagnosis of mastitis, leukocytosis, and reproductive parameters were evaluated in the BLV-N, BLV-PWPL, and BLV-PPL subgroups. The association between clinical or subclinical mastitis and the nosology with BLV infection status was evaluated by Chi-square test using the software Open Epi (Dean, Sullivan, \& Soe, 2013). This test was also used to verify the association between BLV infection status and the number of parturitions, as well as the association between seroconversion of animals initially characterized as BLV-N and the occurrence of mastitis.

The association between the intensity of mastitis, measured from the summation of scores of each mammary quarter in CMT and Tamis test results for each animal, and BLV infection was evaluated by Student's t-test. The Spearman correlation test was used to evaluate the association between lymphocyte counts and the nosology with BLV infection, after verification of the absence of normality in the data using the Shapiro-Wilk test. 


\section{Results and Discussion}

\section{Screening of animals and prevalence of bovine leukosis}

All bovine dairy herds selected for this study were positive for BLV. The prevalence observed in the different herds ranged from $73.28 \%$ to $100.00 \%$, with an average of $83.11 \%$ for lactating cows. The overall prevalence in female cows older than 24 months was $80.89 \%(1126 / 1392)$ (Table 1). Three of the 10 herds initially selected for the work were excluded from the case/control study for the following reasons: in the herd $\mathrm{H}$, BLV prevalence was $100 \%$ in lactating cows and, thus did not present negative animals for the control group (BLV-N); herd I had a high prevalence of clinical and subclinical mastitis and poor general sanitary conditions; and herd $\mathrm{J}$ was removed from participation in the study by the farm owner. Thus, information for the case/control study was collected from seven of the ten herds initially evaluated. In the 1,192 animals analyzed, 1,131 had complete information about the number of births, genealogy, $\mathrm{DL}$, and milk production for the composition of cases and suitable controls.

The high prevalence of BLV observed in this study may be explained by the risk factors favoring its dissemination, which were commonly present in the herds studied. These included the reuse of the palpation gloves and disposable needles for the application of medicines and vaccines and the use of milking machines. These risk factors were as previously related by Kobayashi et al. (2014). On all the farms, no prophylactic and control procedures for BLV infections were adopted; the management was unified; the control of animal ingress in the herds was absent and there was no knowledge about the prevalence of leukosis in the flocks (Almeida et al. 2021).

\section{Table 1}

Prevalence of bovine leukosis among 1,392 lactant cows tested by Agar Gel Immunodiffusion for the detection of antibodies against bovine leukosis virus, distributed by farms from the Mesoregion of Campo das Vertentes/Minas Gerais State/Brazil, from February to December of 2015

\begin{tabular}{|ccc|}
\hline Herds & Number of tested animals & Positive animals (\%) \\
A & 121 & 85.95 \\
B & 233 & 84.12 \\
C & 135 & 82.96 \\
D & 165 & 75.76 \\
E & 107 & 85.05 \\
F & 232 & 73.28 \\
G & 197 & 77.76 \\
H & 60 & 100 \\
I & 65 & 83.08 \\
J & 77 & 79.22 \\
Total & 1,392 & 80.99 \\
\hline
\end{tabular}


Another factor that may have contributed to the high prevalence of BLV was that serodiagnosis was performed only in adult cows. These animals generally present a higher probability of BLV infection because of the longer exposure time in infected herds and risks associated with lack of control procedures. (Birgel et al., 2006; Rajão et al., 2014). This also explains the result for the associationbetweenthenumber of parturitions and BLV infection, with a higher prevalence of BLV in animals with four or more lactations (Table 2). These animals had, on average, more than twice the risk of BLV infections compared to those below four parturitions ( $p<0.05$ ). The intensification of management practices increases the risk of BLV infection (Panziera et al., 2014). Previous studies also pointed out the widespread bovine leukosis among Brazilian cattle herds, including in beef and milk farms. The prevalences pointed in these studies ranging from $9.24 \%$ to $70.86 \%$, depending on the region and the type of the property (milk or meat production) and category of tested animals (Modena et al., 1984; Frandoloso et al., 2008; Juliano, Fioravanti, Brito, Abreu, \& Souza, 2014). Alexandrino et al. (2011) performed a study focusing on the occurrence of BLV, bovine diarrhea virus (BVDV), and bovine herpes virus type-1 (BoHV-1). In agreement with our results, these researchers found that among the animals evaluated (278), 54.68\% were positive for BoHV-1, 69.70\% for BVDV-1, and $34.33 \%(96 / 278)$ for BLV.

\section{Table 2}

Relationship between the number of births and the prevalence of the bovine leukosis among 1,131 cows from seven dairy cattle herds located in the Mesoregion of Campo das Vertentes/Minas Gerais State/ Brazil, from February to December of 2015

\begin{tabular}{cccc} 
Number of births & Positive cows (\%) & P value & OR (IC - 95\%) \\
\hline 1 & $291(75.78)$ & - & - \\
2 & $241(80.33)$ & 0.155 & - \\
3 & $162(79.80)$ & 0.269 & $2.10(1.18-3.73)$ \\
4 & $105(86.78)$ & 0.010 & $2.30(1.28-4.14)$ \\
\hline 5 & $108(87.80)$ & 0.004 &
\end{tabular}

According to hematological parameters, $74.37 \% \quad(119 / 160)$ of BLV-P animals were classified as BLV-PWPL and $25.63 \%(41 / 160)$ as BLV-PPL. Table 3 shows the leukosis attack rates observed among the lactating cows studied. The ratios of BLV-
PWPL and BLV-PPL observed among BLV infect animals were also similar to a previous study that reported persistent lymphocytosis affects $20 \%$ to $30 \%$ of BLV-P animals (Birgel et al., 2006). 


\section{Table 3}

Bovine Leukosis attack rates observed among lactating cows from seven farms located in the mesoregion of Campo das Vertentes/Minas Gerais State/Brazil, distributed by property of origin, from February to December of 2015

\begin{tabular}{ccccc} 
Farms & $\begin{array}{c}\text { Percentual of BLV-P } \\
\text { in the screening tests }\end{array}$ & $\begin{array}{c}\text { Number of } \\
\text { BLV-N cows }\end{array}$ & $\begin{array}{c}\text { Seroconverted } \\
\text { cows }\end{array}$ & Attack rate \\
\hline E & $85.05 \%$ & 15 & 9 & $64.28 \%$ \\
B & $84.12 \%$ & 32 & 19 & $61.29 \%$ \\
C & $82.96 \%$ & 21 & 11 & $57.89 \%$ \\
A & $85.83 \%$ & 12 & 6 & $54.55 \%$ \\
G & $77.66 \%$ & 37 & 11 & $39.28 \%$ \\
D & $75.76 \%$ & 30 & 8 & $30.77 \%$ \\
F & $73.28 \%$ & 49 & 6 & $21.43 \%$ \\
\hline
\end{tabular}

$\mathrm{BLV}-\mathrm{P}=>$ Cows infected by the bovine leukosis virus; $\mathrm{BLV}-\mathrm{N}=>$ Negative cows to infection by bovine leukosis virus.

The high prevalence and infection rates for bovine leukosis in the studied properties, ranging from $21.43 \%$ to $64.28 \%$, showed the high infectivity of the BLV, which can be afforded by intensive management practices and the absence of prophylactic measures to prevent the horizontal dissemination of BLV in dairy cattle as related in previous studies (Kobayashi et al., 2014; Rajão et al., 2014).

\section{Mammary gland health}

On DO, subclinical and clinical mastitis rates were $49.0 \%$ and $3.2 \%$, respectively and at D60, the rates were $54.65 \%$ and $5.67 \%$, respectively. To determine the etiology of clinical and subclinical mastitis cases, 395 milk samples were collected from individual quarters of the animals participating in the case/control study (240 cows) and submitted for microbiological analyses. Among the animals from the control group (BLV-N), 139 milk samples were analyzed, 178 milk samples from the BLV-PWL subgroup, and 78 from the BLV-PPL subgroup. In some cases, more than one sample per animal was collected, depending on the number of positive mammary quarters affected according to CMT or Tamis test results. From the 395 milk samples, five (1.26\%) were contaminated, that is, there was a growth of three or more different types of colonies suggesting contamination, while 97 (24.5\%) showed no microbial growth and 18 (4.55\%) showed mixed growth. A total of 275 milk samples were analyzed, resulting in 275 pure cultures and 311 microorganisms were isolated (Table 4). An increase in the rate of recovered pathogens was observed as the CMT score increased (data not shown). There were no associations between the any of pathogens isolated or between the groups (contagious or environmental pathogens) and the status of BLV infection (BLV-N or BLV-P) ( $p$ $>0.05$ ). 
Table 4

Microorganisms isolated from mastitic cows in D0 e D60, according the nosologic condition of animals to bovine leukosis virus infection in dairy cattle herds located in the Mesoregion of Campo das Vertentes/ Minas Gerais State/Brazil, from February to December to 2015

\begin{tabular}{|cccccccc} 
& \multicolumn{2}{c}{ BLV-N } & \multicolumn{2}{c}{ BLV-PWPL } & \multicolumn{2}{c}{ BLV-PPL } & Total \\
\cline { 2 - 6 } & D0 & D60 & D & D60 & D0 & D60 & D0+D60 \\
Bacillus spp. & 1 & 8 & 0 & 7 & 0 & 9 & 25 \\
Coliforms & 0 & 9 & 3 & 5 & 1 & 1 & 19 \\
Corynebacterium spp. & 4 & 2 & 8 & 4 & 1 & 4 & 23 \\
Enterococcus spp. & 7 & 6 & 4 & 11 & 0 & 1 & 29 \\
Yeasts & 0 & 1 & 0 & 4 & 0 & 1 & 6 \\
Proteus spp. & 1 & 0 & 0 & 0 & 3 & 0 & 4 \\
Staphylococcus aureus & 2 & 4 & 1 & 2 & 1 & 1 & 11 \\
CNS & 22 & 26 & 20 & 47 & 8 & 17 & 140 \\
Streptococcus agalactiae & 2 & 6 & 7 & 2 & 0 & 0 & 17 \\
Streptococcus spp. & 2 & 2 & 6 & 10 & 1 & 6 & 27 \\
Streptococcus uberis & 0 & 0 & 0 & 7 & 0 & 3 & 10 \\
Without growth & 23 & 15 & 28 & 10 & 17 & 4 & 97 \\
Total with growth & 41 & 64 & 49 & 99 & 15 & 43 & 311
\end{tabular}

BLV-N => Negative cows to bovine leukosis virus; BLV-PWPL => Positive cows to bovine leukosis virus without persistent lymphocytosis; BLV-PPL=> Positive cows to bovine leukosis virus with persistent lymphocytosis; CNS => Coagulase negative Staphylococcus.

Among the 311 isolated microorganisms, contagious agents were the predominant ones (61.41\%), while environmental pathogens represented $38.59 \%$ of the isolates. Among the contagious agents, coagulase-negative Staphylococcus (CNS) was predominant (73.30\%), followed by Corynebacterium spp. (12.04\%), Streptococcus agalactiae (8.90\%), and Staphylococcus aureus (5.76\%). Among the environmental pathogens, Enterococcus spp. was the predominant agent (24.17\%), followed by aesculin-negative Streptococcus (22.50\%), Bacillus spp. (20.83\%), coliforms (15.83\%),
Streptococcus uberis (8.33\%), yeasts (5.00\%), and Proteus spp. (3.33\%).

An important finding from this analysis is the high isolation rate of CNS with other pathogens. Several studies also showed the high rates of CNS isolation in dairy cattle herds (Ruiz et al., 2011; Saab et al., 2014; Xu, Tan, Zhang, Xia, \& Sun, 2015). These microorganisms have become the most common mastitis agents in many countries, and they have been considered as emerging bovine mastitis pathogens (Pyorala \& Taponen, 2009; Supré et al., 2011; Mota et al., 2012; ElSeedy, Radwan, Hassan, \& Shehata, 2017). 
Association between BLV infection and mastitis

Table 5 shows the frequencies of clinical and subclinical mastitis in the BLV-N, BLV-PWPL, and BLV-PPL subgroups. There were no significant differences between the rates of clinical or subclinical mastitis among BLV-N cows in the BLV-PPL or BLV-PWPL subgroups ( $p>0.05$ ). In addition, no significant difference was observed in the overall mastitis cases (clinical cases plus subclinical cases) in the same subgroups ( $p>0.05$ ).

\section{Table 5}

Frequency of subclinical and clinical mastitis observed in $\mathbf{2 4 0}$ cows according the nosological condition in relation to bovine leukosis virus infection status in dairy cattle herds located in the Mesoregion of Campo das Vertentes/Minas Gerais State/Brazil, from February to December of 2015

\begin{tabular}{|ccccc|}
\hline BLV status & $\begin{array}{c}\text { Subclinical mastitis } \\
\text { presence (\%) }\end{array}$ & $\begin{array}{c}\text { Clinical mastitis } \\
\text { presence (\%) }\end{array}$ & $\begin{array}{c}\text { Clinical plus } \\
\text { subclinical (\%) }\end{array}$ & $\begin{array}{c}\text { Total of cows in } \\
\text { the subgroup }\end{array}$ \\
\hline BLV-N ${ }^{1}$ & $48(60.0)$ & $8(10.0)$ & $56(70.0)$ & 80 \\
BLV-PWPL $^{2}$ & $79(66.4)$ & $5(4.2)$ & $84(70.6)$ & 119 \\
BLV-PPL $^{3}$ & $31(75.6)$ & $3(7.89)$ & $34(82.9)$ & 41 \\
Total & $158(65.8)$ & $16(6.7)$ & $174(72.5)$ & 240 \\
\hline
\end{tabular}

BLV-N => Negative cows to bovine leukosis virus; BLV-PWPL => Positive cows to bovine leukosis virus without persistent lymphocytosis; BLV-PPL=> Positive cows to bovine leukosis virus with persistent lymphocytosis.

Differences in subclinical mastitis scores were observed between BLV-N and BLV-P animals. Among the BLV-P animals, a higher score of mastitis (median $=4.0$; interquartile distance $=9.0$ ) was observed than those in the control group (BLV-N) (median = 2.5 ; interquartile distance $=6.25)(p=0.015)$. This difference is an indication of a higher prevalence of mastitis in BLV-P animals than in BLV-N animals. Corroborating the hypothesis that BLV-P animals are more predisposed to mastitis, Kakinuma et al. (2014) found that in the peripartum of BLV-infected cows, the mononuclears of the peripheral blood and ones of mammary glands showed higher levels of IL-4 and IL-10 than these same cells in BLV-negative cows. According to these authors, IL-4 and IL-10 activate the humoral response and suppress the cellular response, causing a reduction in the expression of cytokines associated with cellular immunity, such as IL-12 and IFN- $\gamma$, which can lead to immunosuppression and predispose the animals to mastitis.

Although our results did not show an association between persistent lymphocytosis and clinical or subclinical mastitis prevalence, etiology, or disease severity, previous studies have shown a greater predisposition for the occurrence of mastitis in BLV-positive animals with persistent lymphocytosis. Sandev et al. (2004) observed a higher incidence of mastitis in BLV-PPL animals (77.8\%) than in BLV-PWPL (44.4\%) and BLV-N animals (25\%). 
In another study, Blagitz et al. (2017) found that the phagocytic activity of neutrophils and monocytes against Staphylococcus aureus was decreased in BLV-P cows, especially in those with persistent lymphocytosis. These authors observed that the proportion of neutrophils expressing ROS was lower in BLV-PPL cows, in contrast to the higher intensity of ROS production by monocytes and that in BLV-P cows. In addition, the relative percentage of monocytes and CD44+ neutrophils and the expression of CD11b by neutrophils were also lower in cows with persistent lymphocytosis. These changes in the functionality of the phagocytes of the mammary gland can decrease the action of these important components of the innate immune system, increasing the susceptibility to mastitis.

The proviral load in the course of infection and the viral types circulating in the flocks are factors that can contribute to the evolution of leukosis and comorbidities in herds. In the case of mastitis, the BLV load can influence the greater or lesser predisposition to the disease and the severity of clinical manifestations, as shown by Watanabe et al. (2019). These authors found that BLV-P animals with a high viral load were more likely to present with more severe clinical mastitis than those with low viral load.

Another aspect that may justify our results is the high genetic variability among BLV isolates. According to Brogniez, Mast and Willems (2016), the pathogenicity of BLV varies depending on the genetic variants circulating in herds. Phylogenetic studies based on genomic sequencing and the gp51 envelope protein have pointed out the existence of 10 BLV genotypes with a wide worldwide distribution. In South America, genotypes I, II,
IV, V, VII, and IX have already been identified, and in Brazil genotypes I, II, V, VI, and VII (Polat, Takeshima, \& Aida, 2017; Gregory et al., 2017). In a study performed in Santa Catarina State/Brazil, it was observed the circulation of genotypes I, II, VIII, IX, and the genotype $X$ as the most prevalent (47\%) (Rodakiewicz et al., 2018). Yu et al. (2019) identified a new genotype (G11) in genotypic studies of BLV types circulating in Heilongjiang, northeast China.

Our results indicated that BLV infection in cattle increases the risk for the development of mastitis; however, environmental factors, cattle management practices, and genetic differences between the animals, as well as differences in the virulence of BLV strains that circulate in different herds may contribute to interactions between leukosis and mastitis. In addition, this study demonstrates the importance of adopting control measures for bovine leukosis in dairy herds owing to direct losses (development of lymphomas and sanitary barriers) and indirect losses, due to the high predisposition of affected animals to secondary comorbidities, especially mastitis.

\section{Conclusions}

BLV infection is widespread in dairy herds. Persistent lymphocytosis was observed in $26 \%$ of BLV-positive animals. The association between the number of parturitions and BLV infection was observed, with a higher prevalence of BLV in animals with four or more lactations. A high prevalence of subclinical mastitis was observed in the flocks evaluated. Contagious microorganisms were predominant, but no association was observed between the type of pathogen and BLV infection status. BLV-P animals presented 
higher scores in CMT than BLV-N animals, suggesting a greater severity of subclinical mastitis in cows affected by BLV.

\section{Acknowledgments}

We wish to thank the Coordenação de Aperfeiçoamento de Pessoal de Nível Superior (CAPES), for the granting the master's scholarship to carry out this study.

\section{References}

Acosta, A. C., Silva, L. B. G. D., Medeiros, E. S., Pinheiro, J. W., Jr., \& Mota, R. A. (2016). Mastites em ruminantes no Brasil. Pesquisa Veterinária Brasileira, 36(7), 565573. doi: 10.1590/S0100-736X2016000 700001

Alexandrino,B.,Dias, F.C., Oliveira, M.C.,Affonso, I. B., Pereira, G. T., \& Samara, S. I. (2011). Bovine Herpesvirus associated with Bovine Viral Diarrhea and Enzootic Bovine Leukosis. Ars Veterinária, 27(3), 168-174. doi: $\quad 10.15361 / 2175-0106.2011 v 27 n 3 p$ 168-174

Almeida, I. C., Almeida, S. L. H., Barioni, G., Donatele, D. M., Clipes, R. C., Siqueira Glória, L., \& Di Filippo, P. A. (2021). Seroprevalence and influence of bovine leukemia virus on the incidence of mastitis in dairy herds. Acta Scientiae Veterinariae, 49, 1783. doi: 10.22456/1679-9216.109458

Azedo, M. R., Blagitz, M. G., Souza, F. N., Benesi, F. J., \& Della Libera, A. M. M. P. (2011). Avaliação funcional de monócitos de bovinos naturalmente infectados pelo vírus da leucose bovina. Arquivo Brasileiro de Medicina Veterinária e Zootecnia, 63(5), 1131-1140. doi: 10.1590/S01020935201000500013

Bendixen, H. J. (1958). Undersogelser over kvaegets leukose. 2. Kvaegleukonsens kliniske diagnostik. Nordisk Veterinaer Medicin, 10, 273-301.

Birgel, E., Jr., Dias, W. M. C., Souza, R. M., Pogliani, F. C., \& Birgel, D. B. (2006). Prevalência da infecção pelo vírus da leucose dos bovinos em animais da raça semental criados no Estado de São Paulo. Ars Veterinária Jaboticabal, 22(2), 122129. doi: $10.15361 / 2175-0106.2006 v 22$ n2p122-129

Blagitz, M. G., Souza, F. N., Batista, C. F., Azevedo, L. F. F., Sanchez, E. M. R., Diniz, S. A., \& Della Libera, A. M. M. P. (2017). Immunological implications of bovine leukemia virus infection. Research in Veterinary Science, 114, 109-116. doi: 10.1016/j.rvsc.2017.03.012

Brogniez, A., Mast, J., \& Willems, L. (2016). Determinants of the bovine leukemia virus envelope glycoproteins involved in infectivity, replication and pathogenesis. Viruses, 8(4), 88. doi: 10.3390/v804 0088

Costa, G. M. (2014). Mastite bovina. In J. C. P. M. da Silva, C. M. Veloso, M. de O. Franco, \& A. S. de Almeida. (Org.), Manejo e administração na bovinocultura leiteira (2a ed., pp. 391-421). Viçosa, MG: Universidade do Leite.

Dean, A. G., Sullivan, K. M., \& Soe, M. M. (2013). OpenEpi: open source epidemiologic statistics for public health, Version 3.01. Recovered from https://www.openepi. com/Menu/OE_Menu.htm 
Della Libera, A. M. M. P., Souza, F. N., Batista, C. F., Santos, B. P., Azevedo, L. F. F., Sanchez, E. M. R., \& Blagitz, M. G. (2015). Effects of bovine leukemia virus infection on milk neutrophil function and the milk lymphocyte profile. Veterinary Research, 46(1), 2. doi: 10.1186/s13567-014-0125-4

El-Seedy, F. R., Radwan, I. A., Hassan, W. H., \& Shehata, A. (2017). Coagulase negative Staphylococci as an emerging cause of bovine mastitis: prevalence, antimicrobial resistance and biofilm formation. Journal of Veterinary Medical Research, 24(1), 1-11. doi: 10.21608/JVMR.2017.43256

Frandoloso, R., Kreutz, L. C., Anziliero, D., Spagnolo, J., Kuse, N., Fiori, C., \& Scortegagna, G. T. (2008). Prevalência de leucose enzoótica bovina, diarréia viral bovina rinotraqueíte infecciosa bovina e neosporose bovina em 26 propriedades leiteiras da região nordeste do Rio Grande do Sul, Brasil. Ciência Animal Brasileira, 9(4), 1102-1106. Recovered from https:// revistas.ufg.br/vet/article/view/1398

Gregory, L., Gaeta, N. C., Araújo, J., Thomazelli, L. M., Harakawa, R., Ikuno, A. A., \& Pituco, E. M. (2017). Bovine leukaemia virus genotypes 5 and 6 are circulating in cattle from the state of São Paulo, Brazil. Journal of Medical Microbiology, 66(12), 17901797. doi: 10.1099/jmm.0.000639

International Committee on Taxonomy of Viruses (2021). Virus Taxonomy: 2020 Bovine Leukemia Virus. Retrieved from https://talk.ictvonline.org/taxonomy/

Juliano, R. S., Fioravanti, M. C. S., Brito, W. M. E. D., Abreu, U. G. P., \& Souza, S. N. (2014). Soroepidemiologia da leucemia bovina (LB) em bovinos curraleiros dos estados de Goiás e Tocantins, Brasil. Ciência
Animal Brasileira, 15(3), 289-295. doi: 10.1590/1809-6891v15i313369

Kakinuma, S., Maeda, Y., Ohtsuka, H., Konnai, S., \& Oikawa, M. (2014). Bovine Leukemia virus titer and leukocyte population associated with mastitis in periparturient dairy cows. International Jounal of Applied Research Veterinary Medicine, 12(3), 239-244. Recovered from https://www.researchgate.net/ publication/279113906

Kobayashi, S., Hidano, A., Tsutsui, T., Yamamoto, T., Hayama, Y., Nishida, T., \& Murakami, K. (2014). Analysis of risk factors associated with bovine leukemia virus seropositivity within dairy and beef breeding farms in Japan: a nationwide survey. Research in Veterinary Science, 96(1), 47-53. doi: 10. 1016/j.rvsc.2013.11.014

Modena, C. M., Abreu, V. L. V., Silva, J. A., Moreira, E. C., Azevedo, N. A., \& Rehfeld, O. A. M. R. (1984). Enzootic bovine leucosis: I Prevalence in high lineage herds in the State of Minas Gerais. Arquivo Brasileiro de Medicina Veterinária e Zootecnia, 36(1), 39-45. Recovered from https://agris.fao. org/agris-search/search.do?request_loca le $=$ fr\&recordID=BR19850061517

Mota, R. A., Medeiros, E. S. de, Santos, M. V. dos, Pinheiro, J. W., Jr., Moura, A. P. B. L., \& Coutinho, L. C. A. (2012). Participation of Staphylococcus spp. in the etiology of mastitis in dairy cattle in the State of Pernambuco (Brazil). Ciência Animal Brasileira, 13(1), 124-130. doi: 10.5216/ cab.v13i1.3790

Norby, B., Bartlett, P. C., Byrem, T. M., \& Erskine, R. J. (2016). Effect of infection with bovine leukemia virus on milk production in Michigan dairy cows. Journal of Dairy 
Science, 99(3), 2043-2052. doi: 10. 3168/ jds.2015-10089

Oliver, S. P., González, R. N., Hogan, J. S., Jayarao, B. M., \& Owens, W. E. (2004). Microbiological procedures for the diagnosis of bovine udder infection and determination of milk quality. A Global Organization for Mastitis Control and Milk Quality. (4th ed.), Verona, WI, USA: National Mastitis Council Inc.

Panziera, W., Bianchi, M. R., Galiza, G. J., Pereira, P. R., Mazzaro, R. D., Barros, C. S. L., \& Fighera, R. A. (2014). Epidemiological, clinical and anatomopathological aspects of lymphoma in cattle: 128 cases (19652013). Pesquisa Veterinária Brasileira, 34(9), 856-864. doi: 10.1590/S0100-736X 2014000900009

Polat, M., Takeshima, S., \& Aida, Y. (2017). Epidemiology and genetic diversity of bovine leukemia virus. Virology Journal, 14(1), 209. doi: 10.1186/s12985-017-08 76-4

Pyorala, S., \& Taponen, S. (2009). Coagulasenegative staphylococci-emerging mastitis pathogens. VeterinaryMicrobiology, 134(12), 3-8. doi: 10.1016/j.vetmic.2008.09.015

Rajão, D. S., Heinemann, M. B., Reis, J. K. P., Braz, G. F., Haddad, J. P. A., Ribeiro, A. C. C. L., \& Leite, R. C. (2014). Effects of bovine leukemia virus infection on crossbred and purebred dairy cattle productive performance in Brazil. Semina: Ciências Agrárias, 35(2), 891-900. doi: 10.5433/1679-0359. 2014v35n2p891

Rodakiewicz, S. M., Fernandez, M. L., Munhoz, M. L., Yamakawa, F. H. S., Urio, M., Forell, F., \& Costa, U. M. (2018). Heterogeneity determination of bovine leukemia virus genome in Santa Catarina state, Brazil. Arquivos do Instituto Biológico, 85,1-7, e0742016. doi: 10.1590/1808-1657000 742016

Rueg, P. (2017). A 100-Year review: mastitis detection, management, and prevention. Journal of Dairy Science, 100(12), 1038110397. doi: 10.3168/jds.2017-13023

Ruiz, A. K., Ponce, P., Gomes, G., Mota, R. A., Sampaio, E., Lucena, E. R., \& Benone, S. (2011). Prevalence of subclinical bovine mastitis and associated microorganisms: a comparison between manual and mechanical milking. Revista de Salud Animal, 33(1), 57-64. Recovered from https://www.cabdirect.org/cabdirect/Full TextPDF/2011/20113202025.pdf

Saab, A.B.,Zamprogna, T. O., Lucas, T.M., Martini, K. C., Mello, P. L., Silva, A. V., \& Martins, L. A. (2014). Prevalence and etiology of bovine mastitis in the Nova Tebas region, Paraná. Semina: Ciências Agrárias, 35(2), 835844. doi: 10.5433/1679-0359.2014v35n 2 p835

Sandev, N., Koleva, M., Binev, R., \& llieva, D. (2004). Influence of enzootic bovine leukosis virus upon the incidence of subclinical mastitis in cows at a different stage of lactation. Veterinarski Archiv, 74(6), 411-416. Recovered from https:// www.researchgate.net/publication/2262 66985

Santos, M. V., \& Fonseca, L. F. L. (2019). Controle da mastite e qualidade do leite: desafios e soluções. São Paulo: Manole.

Silva, A. J., Souza, F. N. de, Blagitz, M. G., Batista, C. F., Bellinazzi, J. B., Nobre, D. S. M.,\& Della Libera, A. M. M. P. (2018). Implications of bovine viral diseases 
for udder health. Brazilian Journal of Veterinary Research and Animal Science, 55(3), 1-13. doi: 10.11606/issn.1678-44 56.bjvras.2018.140200

Supré, K., Haesebrouck, F., Zadoks, R., Vaneechoutte, M., Piepers, S., \& De Vliegher, S. (2011). Some coagulasenegative Staphylococcus species affect udder health more than other. Journal of Dairy Science, 94(5), 2329-2340. doi: 10.3168/jds.2010-3741

Trainin, Z., \& Brenner, J. (2005). The direct and indirect economic impacts of bovine leukemia virus infection on dairy cattle. Irish Journal Veterinary Medicine, 60(3), 94-105. Retrieved from https://www. researchgate.net/publication/303260670

Watanabe, A., Murakami, H., Kakinuma, S., Murao, K., Ohmae, K., Isobe, N. \& Kawai, K. (2019). Association between bovine leukemia virus proviral load and severity of clinical mastitis. The Journal of Veterinary Medical Science, 81(10), 1431-1437. doi: 10.1292/jvms.19-0285
Xu, J., Tan, X., Zhang, X., Xia, X., \& Sun, H. (2015). The diversities of staphylococcal species, virulence and antibiotic resistance genes in the subclinical mastitis milk from a single Chinese cow herd. Microbial Pathogenesis, 88, 29-38. doi: 10.1016/j. micpath.2015.08.0

Yang, Y., Fan, W., Mao, Y., Yang, Z., Lu, G., Zhang, R., \& Wang, C. (2016). Bovine leukemia virus infection in cattle of China: association with reduced milk production and increased somatic cell score. Journal of Dairy Science, 99(5), 3688-3697. doi: 10.3168/jds.2015-10580

Yu, C., Wang, X., Zhou, Y., Wang, Y., Zhang, X., \& Zheng, Y. (2019). Genotyping bovine leukemia virus in dairy cattle of Heilongjiang, northeastern China. Veterinary Research, 15, 179. doi: 10.11 86/s12917-019-1863-3 
